\title{
Study on Herpes Zoster Conducted in HIV/AIDS Albanian Adults
}

\author{
Esmeralda Meta ${ }^{1}$, Pellumb Pipero ${ }^{2}$, Dhimiter Kraja ${ }^{3}$ \\ University Hospital Center "Mother Theresa”, Department of Infectious Diseases and Out Patient HIV/AIDS Clinic, Tirana, Albania
}

\begin{abstract}
Herpes zoster is currently recognized as one of the major opportunistic infections of HIV / AIDS. It may appear at the first time of HIV infection or AIDS, and in the case of immune recovery after the initiation of ART. We studied 481 cases with HIV / AIDS registered in Infectious diseases services and out patient clinic of HIV / AIDS, of UHC "Mother Theresa". 61 of them resulted Hepes zoster. We analyzed the time of occurrence of Zoster in these subjects, the CD4 + level at the time of diagnosis, localization of vesicles, the type and density of them, his appearance at the time of immune recovery. We analyzed also some of the epidemiological aspects and co-infections manifested at the same time in these subjects. From them 63.9\% were male, age group $31-40$ years old and $41-50$ years old respectively resulted affected $31.14 \%$ and $34.45 \%$, was encountered 24 types concomitant opportunistic infections; In 31.1\% of cases CD4 + was seen in limits $100 \mathrm{cel} / \mathrm{mm} 3-250 \mathrm{cel} / \mathrm{mm} 3$. In $40.32 \%$ predominated thoracic localization of vesicular elements followed by $19.35 \%$ from that thoraco-lumbar. Ulcero hemorrhagic forms were encountered in $12.16 \%$. Morality occurred in $6.55 \%$
\end{abstract}

Keywords: Zoster, HIV/AIDS, Albania

\section{Introduction}

Herpes Zoster has been known since ancient times as a unique clinical entity due to dermatomes vesicular rash; it represents the activation of the human herpes virus 3 that has given partial immunity after a previous attack by the Varicella (chickenpox) ${ }^{[13]}$. Herpes zoster represents a clinical variety, it manifests the highest gravity to immunocompromised patients than in patients with normal immunity ${ }^{\left.[7]^{[8}\right]}$ The incidence in these subjects is 10 times higher than in immunocompetent ${ }^{[11]}$ Immunocompromised patients have lesions often more numerous and require a longer time to heal than in patients with normal immunity ${ }^{[9]}$. They are also at higher risk for complications of internal organs, which can range in 30-50\% of cases and is fatal in $15 \%$ of them in the absence of antiviral therapy. ${ }^{[10]}$

A depressed immune system may play an important role in reactivation of $\mathrm{VZ}$ virus. Its association with impaired cell modiated immunity due to various causes is well known ${ }^{[1]}$ In last few years its association with HIV infection has been reported by several workers. ${ }^{[2][3][4]}$ The development of herpes zoster has been reported to be a possible early clinical sign for development of AIDS in high risk individual by some workers ${ }^{[5]}$. A eight year follow up study of herpes zoster in HIV infected patients is presented in this study.

\section{Material}

We got to study 481 cases of HIV / AIDS registered in the service of infectious diseases and outpatient clinic of HIV / AIDS in UHC Tirana, during the period 2007 to 2015, studied age group 16-81 years old.

\section{Methods}

The study is retrospective analytical type. The diagnosis of herpes zoster was made clinically on the basis of characteristic presentation of vesicles in dermatome or disseminated pattern. Diagnose of HIV positive cases was based on ELISA and Western Blott methods. We analyzed some epidemiological aspects of the persons appearing, immunological stage, the level of CD4 + cells at the time of diagnosis, when zoster had done during the progression of disease recurrence, as well as the manifestation of IRIS cases after initiation of therapy with HAART. We searched for co-infections manifested at the same time in these subjects, Co- pathologies such as HBsAg, anti HCV, TB and Syphilis. Underlined the herpes zoster cases where it's appeared before AIDS diagnosis (we included here manifested of zoster to 5 years before diagnosis of HIV), at the time of diagnosis and screening during immune recovery syndrome. We described clinical evaluation regarding the segment of involvement, morphology pattern of lesions and disseminations.

\section{Results}

- 61 cases resulted Zoster in 481 analyzed with HIV/ AIDS in different stage

- According to the epidemiological aspect $63.93 \%$ males and $36.06 \%$ females

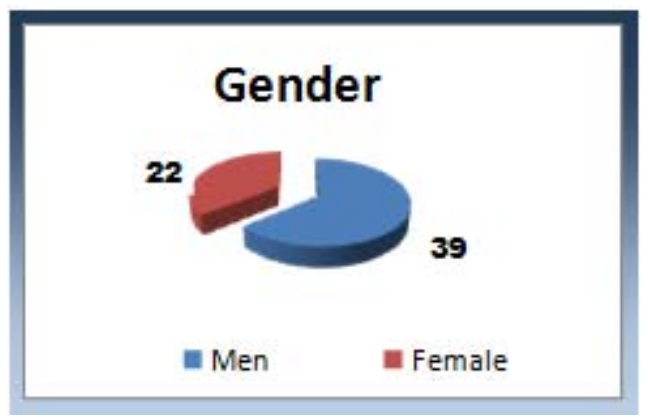

Graphic 1: Distribution between men and female

- Based on age group: 15-20 years old 2 cases, 21 - 30 years old 2, $31-40$ years old $19,41-50$ years old 21,51 - 60 years old $13,61-70$ years old $3,71-80$ years old 1 case

\section{Volume 4 Issue 12, December 2015}




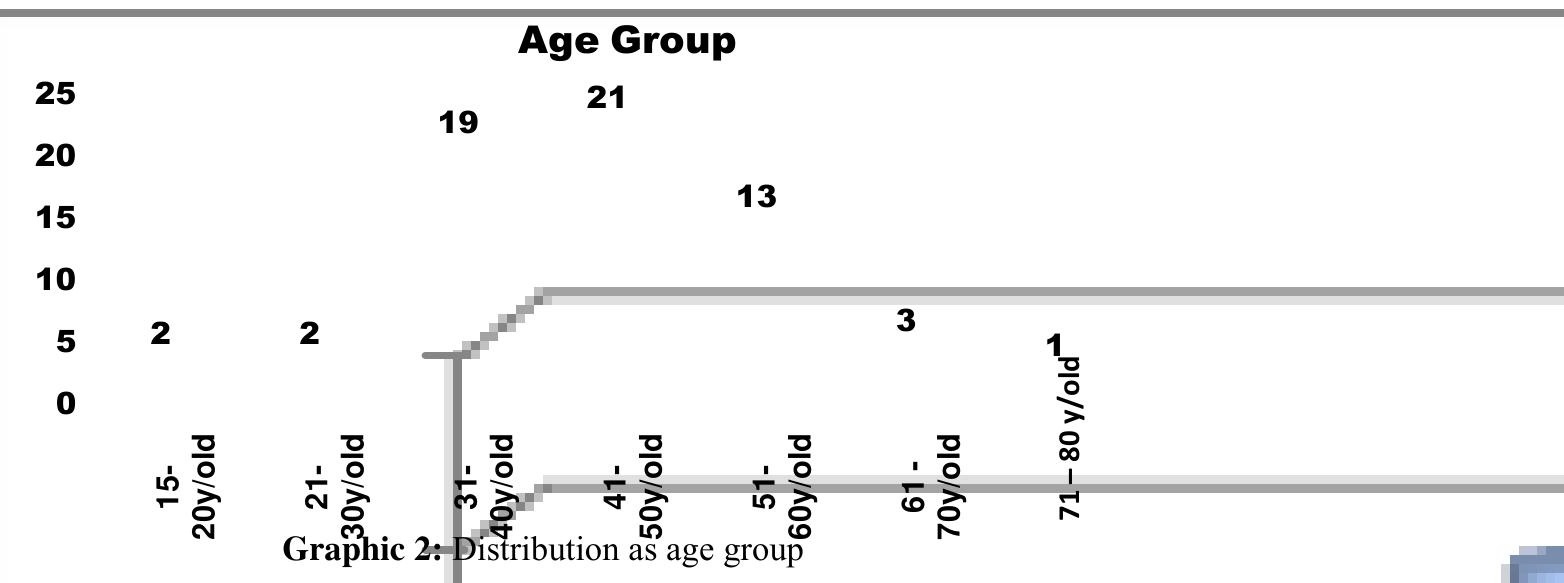

- Herpes zoster appeared before AIDS diagnosis in 19 cases, at the time of diagnosis 22 , during immune recovery syndrome 17 cases, and as a result of failure to ART 6 cases

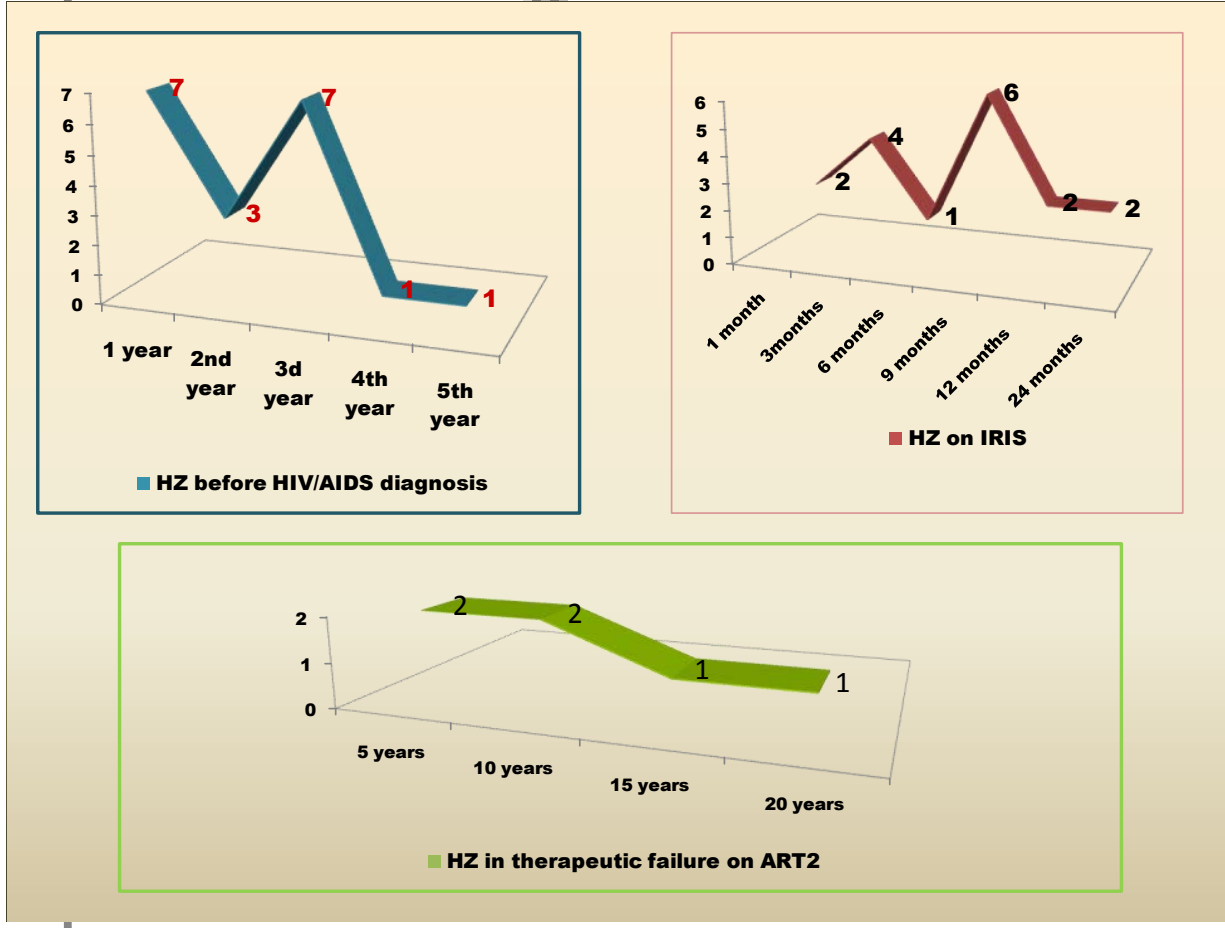

Graphic 4: Distribution of appearance of Zoster based on HIV/AIDS stage

- Based on the stage immunological with CD4 $+<100$ cell / $\mathrm{mm} 3$ were 13 cases, CD4 + between $100-250$ cell / mm3
19, CD4 + 250cell / mm3 - 350 cell / mm3 9, CD4 + on 350 cell / $\mathrm{mm} 37$ cases, 7 cases had no data on CD4 +

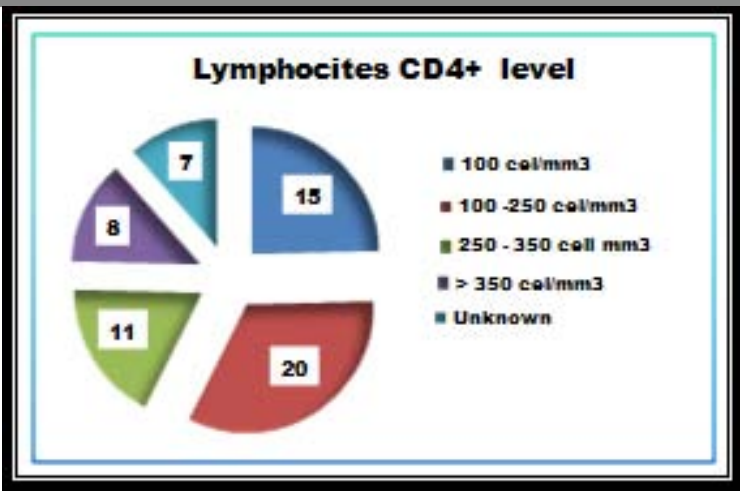

Graphic 4: $\mathrm{Nr}$ of cases based on CD4+ level in diagnostic moment of HIV/AIDS

- Zoster recurrence up 2 episodes resulted in 6 cases, 3 were during IRIS.
- Were identified 20 species of the associated opportunistic infections

\section{Volume 4 Issue 12, December 2015}

\section{www.ijsr.net}


International Journal of Science and Research (IJSR)

ISSN (Online): 2319-7064

Index Copernicus Value (2013): 6.14 | Impact Factor (2014): 5.611

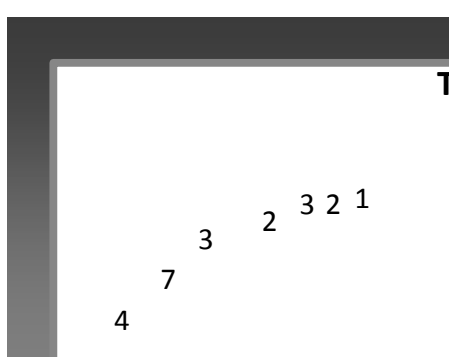

10

5
The associated opportunistic infections

9

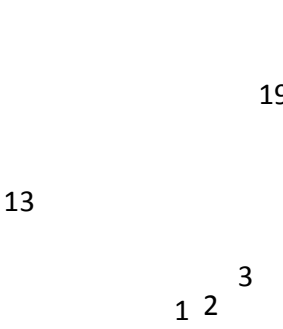

1

Wastin syndrome

Lymphome

oral candidosis

HC leucoplakia

Herpetic infections

psoriasis

pneumonia

onychomycosis

chronic diarrea

Kaposi sarcoma

LAS

Seborroic dermatitis

CMV ocular-form

Anal condiloma

Cerebral Toxoplasmosis

alopecia

Hematologic disorders

Neuropathia

Bacilar angiomatosis

other STD

Graphic 5: Distribution of associated opportunistic infections on Herpes Zoster cases

- In Co pathologies HIV - HBV were 6 cases, HIV - TB 5, HIV - Syphilis 13
Based on CDC clinic classification: A2 2 cases, A3 1, B1 2, B2 8, B3 15, C1 1, C2 2, C3 17 cases

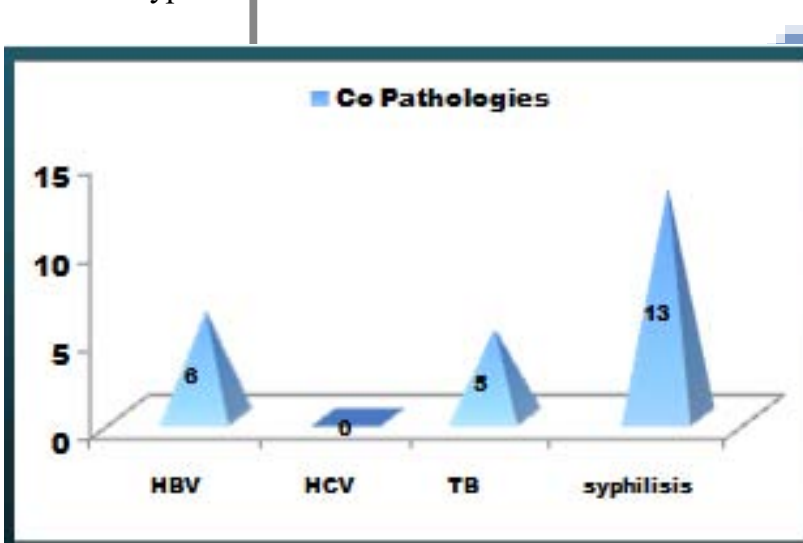

Graphic 6: Co pathologies

19 of cases are hospitalized as a result of the gravity of this virosis, dermatomes dissemination gravity of eruptions, and herpetic neuralgia that was present

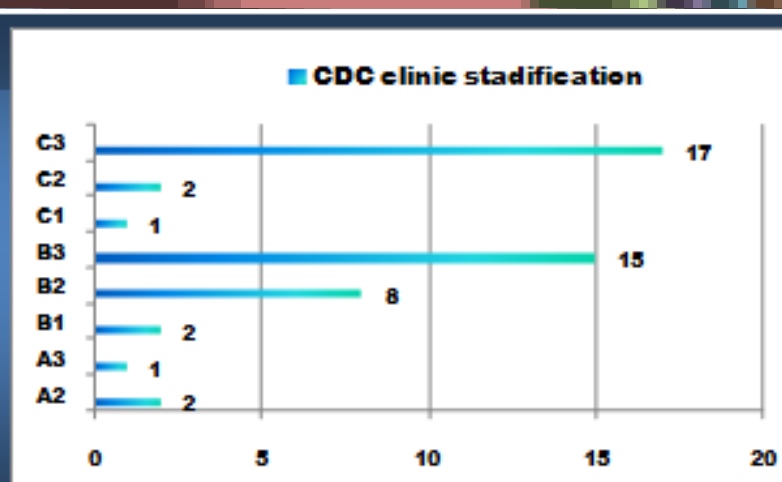

Graphic 7: CDC clinic classification

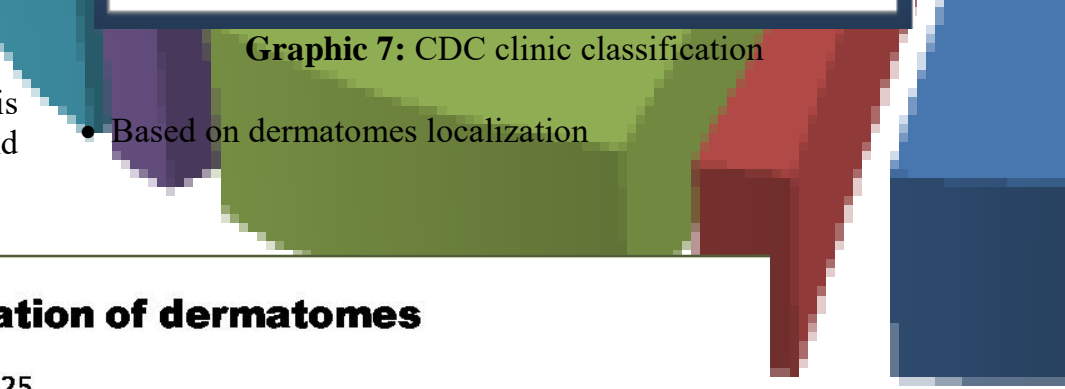

25

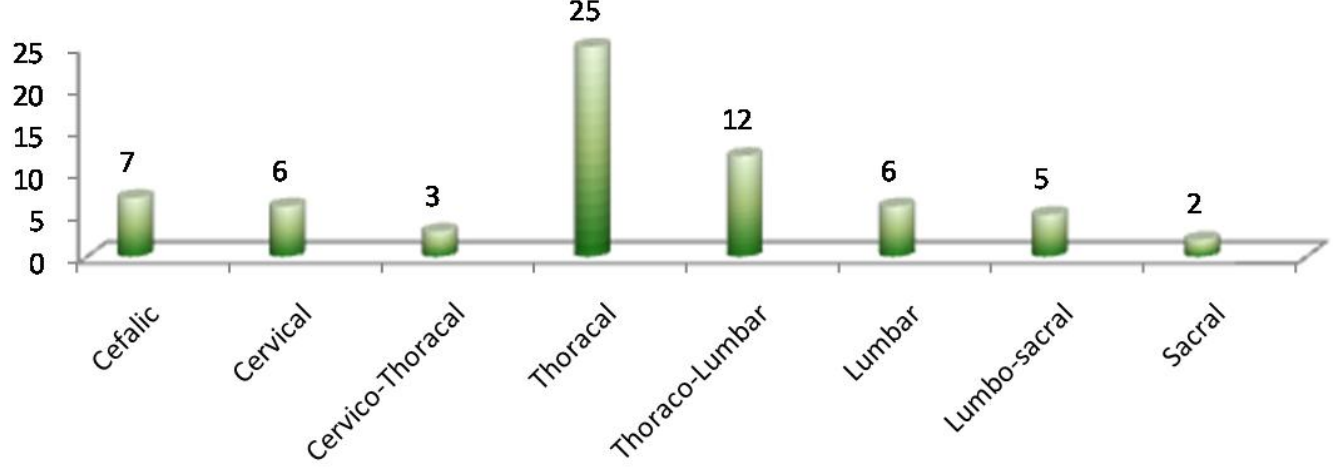




\section{International Journal of Science and Research (IJSR) \\ ISSN (Online): 2319-7064}

Index Copernicus Value (2013): 6.14 | Impact Factor (2014): 5.611

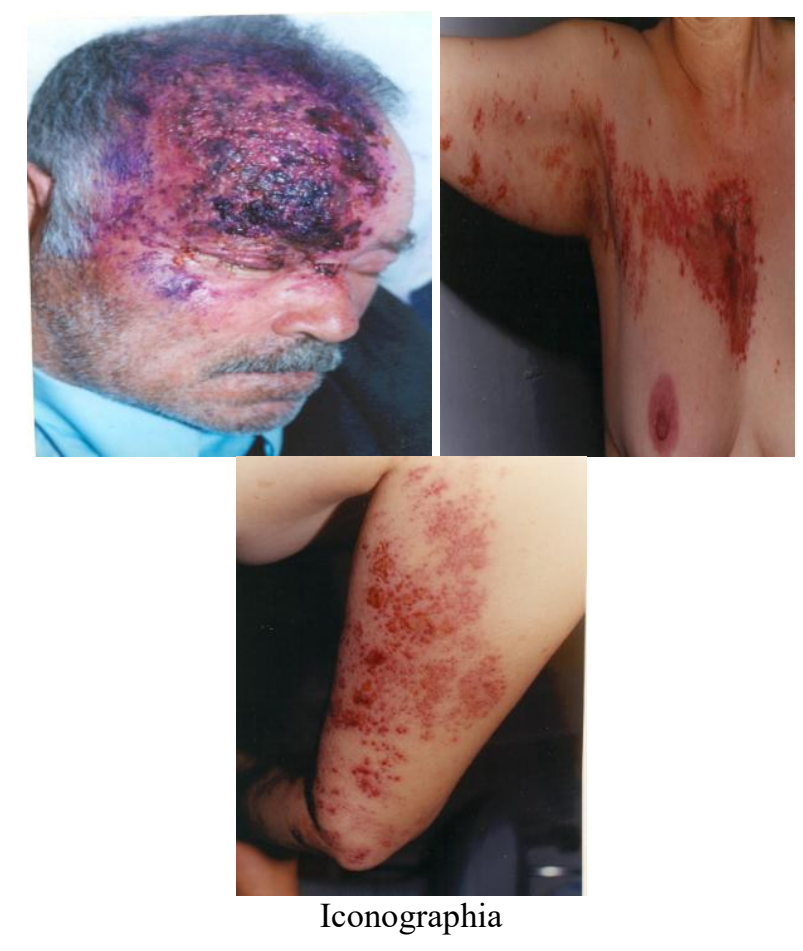

\section{Conclusion}

From 481 cases of HIV / AIDS included in our study herpes zoster resulted in $12.68 \%$. Prevailing men in relation to women with $63.93 \%$. Age group 31- 40 years old and $41-50$ years old resulted more affected, respectively $31.14 \%$ and $34.45 \%$. Based on immunological level it was at top CD4 + between $100 \mathrm{cel} / \mathrm{mm}^{3}$ to 250 cel $/ \mathrm{mm}^{3}$ were $32.78 \%$. Reccurence on two episodes had become 11:47\%. Identified 20 types of concomitant opportunistic infections and 4 types of Co pathologies. With the highest number of zoster cases constituted at the time of HIV / AIDS diagnosis $36.06 \%$. In $40.32 \%$ thoracic localization of vesicular elements ranked above followed by thoraco-lumbar with 19:35\% Ulcero hemorrhagic forms were encountered in $12.16 \%$. Exitus letalis resulted $6: 55 \%$ of them The data concluded suggested to increase attention to this virus as the first manifestation of HIV / AIDS. It presents a particular challenge and requires individual treatment decisions.

\section{References}

[1] Wellar TH. Vericella and herpes zoster: changing concepts of the natural history, control and importance of a not so benign virus. N Engl J Med 1983, 309:136268.

[2] Marshell JG, Richard DM, Richard EC, et al. Herpes zoster and human immune deficiency virus infection. $\mathrm{J}$ Infec Dis 1993; 168:1264-8.

[3] Buchinder SP, Katz MH, Hessel NA, et al. Herpes zoster and human immunodeficiency virus infection. $\mathrm{J}$ Infec Dis 1992;166:1153-6.

[4] Hira S K. Clinical profile of HIV $1 / 2$ infection in Mumbai. Proceedings of the National Conference on HIV/AIDS Medicine. 1996 Nov 23-24 Pune, India.

[5] . 5. Friedman Kien AE, Lafleur FL, Gandler E, et al. Herpes zoster:a possible early clinical sign for development of AIDS in high risk individual. J Am Acad Dermatol 1986; 14:1023
[6] Whitley RJ. Varicella zoster virus. In: Mandell GL, Bennet JE, Dolin R, editors. Principles and practice of infectious diseases. 4th ed. New York: Churchill Livingstone; 1995. pp. 1345-51.

[7] Schacker T, Corey L. Herpes virus infections in HIV infected person. In: Devita VT, Hailman Samuel, Lisenberg SA, editors. Textbook of AIDS. 4th ed. Philadelphia: Lippincott - Raven; 1997. pp. 267-80.

[8] Smith KJ, Skelton HG, Yeager J. Cutaneous findings in HIV - 1 positive patients: A 42 - months' prospective study. J Am Acad Dermatol. 1994;3:746-54. [PubMed]

[9] Gulick RM. Varicella zoster virus disease in patients with human immunodeficiency virus infection. Arch Dermatol. 1990;126:1086-8. [PubMed]

[10] Das AL, Sayal SK, Gupta CM. Herpes zoster in patients with HIV infection. Indian J Dermatol Venereol Leprol. 1997;63:101-14. [PubMed].

[11] Kar PK, Ramasastry CV. HIV prevalence in patients with Herpes Zoster. Indian J Dermatol Venereol Leprol. 2003;69:116-9. [PubMed].

[12] Gilson IH, Barnett JH, Conant MA. Disseminated ecthymatous herpes varicella zoster virus infection in patients with acquired immunodeficiency syndrome. J Am Acad Dermatol. 1989;20:637-42. [PubMed].

[13] Varsha D, Subhash H, Chetan O. Natural history of herpes zoster in the era of AIDS. Indian J Dermatol Venereol Leprol. 1998;64:169-72. [PubMed] 